\title{
Diagnosis and Management of Pre-Partum Paresis in a Goat
}

\author{
B. R. Babji*, J. Jyothi and G. Abhinav Kumar Reddy \\ Department of Veterinary Medicine, College of Veterinary Science, Rajendranagar, \\ Hyderabad-500030, India \\ *Corresponding author
}

\section{A B S T R A C T}

\begin{tabular}{|c|}
\hline $\begin{array}{l}\text { Ke y w o r d s } \\
\text { goat, parturient } \\
\text { paresis, } \\
\text { treatment }\end{array}$ \\
\hline Article Info \\
\hline $\begin{array}{l}\text { Accepted: } \\
10 \text { April } 2020 \\
\text { Available Online: } \\
10 \text { May } 2020\end{array}$ \\
\hline
\end{tabular}

The parturient paresis is a production disease in high yielding lactating cattle during its first 24-72 hrs of parturition or during last few days of pregnancy in sheep/goat, characterized by acute deficiency of ionized calcium in the blood resulting in progressive neuromuscular dysfunction with flaccid paralysis and death in 2-3 days. A 2-year old pregnant doe was presented with a history and signs of sternal recumbency, curvature and twisting of neck, depression and anorexia to the Veterinary Clinical Complex (VCC), College of Veterinary Science, Rajendranagar, Hyderabad. No abnormality was detected on physical examination and urine analysis. Abdomen x-ray revealed fully developed skeleton of four feti. Serum analysis showed a low levels of calcium $(6.4 \mathrm{mg} / \mathrm{dl})$ giving a confirmation for parturient paresis (pre parturient hypocalcemia). The doe was treated with calcium gluconate, oral calcium powder and nervine tonics which showed a complete recovery after 5 days.

\section{Introduction}

Because of goats' potential for high milk production and their tendency to have multiple births and relatively large fetoplacental requirements, prepartum occurrence of hypocalcaemia in this species is a common finding (Allen WM et al., 1986). Whereas, (Anderson, J. J. B.1968) documented that the parturient paresis in pregnant and lactating ewes and does is a common metabolic disturbance characterized by acute-onset of hypocalcaemia caused by a decrease in calcium intake under conditions of increased calcium requirements, usually during late gestation and rapid development of hyperexcitability and ataxia, posterior paralysis progressing to depression, recumbency, coma and death.

Unlike parturient paresis in dairy cattle, which primarily occurs within a few days of calving, the greatest demand for calcium occurs 3 to 4 weeks before parturition in goats with more 
than one fetus as a result of calcification of foetal bones (Pugh 2002). The pregnant animals with multiple foetuses, some of which are complicated by concurrent pregnancy toxaemia are more prone for the condition(Frank K Ramsey1945). Parturient paresis can occur at any time from 6 weeks before to 10 weeks after parturition; however, the greatest demand for calcium because of mineralization of the foetal skeleton occurs 13 wk prepartum, particularly when multiple foetuses are present in utero (Radostits et al., 2006 \& JP Goff and RL Horst, 1997). The present paper puts on record about the diagnosis of prepartum paresis and its successful management in a doe.

\section{Materials and Methods}

The present investigation was carried out in the VCC, College of Veterinary Science, Rajendranagar, Hyderabad. A non-descript doe of 2 years was presented with the history and signs of sternal recumbency, depression and anorexia for a couple of days. The owner was not sure about the pregnancy status of the animal. Physical examination ruled out the fracture/dislocation but with normal muscle tonicity. Blood sample was collected and examined for serum chemistryand urine collected for analysis of ketone bodies. Further, abdomen $\mathrm{x}$ ray was also taken to rule out pregnancy.

\section{Results and Discussion}

Anorexia, suspended rumination, stupor, sternal recumbancy and twisting of neck were the clinical signs noticed in the present nondescript doe at the time of presentation (fig.1 \&2). Subnormal rectal temperature $\left(99^{\circ} \mathrm{F}\right)$, feeble pulse with bradycardia, insensible respirations, rumen atony and moderate dehydration were the important observations. Low levels of serum calcium $(6.4 \mathrm{mg} / \mathrm{dl})$ along with normal levels of blood glucose were the biochemical findings. Urine analysis of the present doe revealed a negative Rotheras test suggesting absence of ketone bodies (fig.3). Further, abdomen x-ray revealed presence of fully developed fetal skeleton of(4) foetus (fig.4). Based on these findings the case was diagnosed as periparturient paresis and then treated with slow intravenous infusion of calcium gluconate @ $25 \mathrm{ml}$ (fig.5) along with dextrose normal saline @300 ml i/v, amoxicillin sodium and clavulanate @ $10 \mathrm{mg} / \mathrm{kg} \mathrm{i} / \mathrm{m}$ followed by oral calcium powder and nervine tonics for 3 days. Animal started showing improvement from day 2 and by day 3 there was no lateral deviation of neck (fig.6). By day 5 (fig.7) the doe was back to her normal physical activity, posture and appetite along with normal carriage of neck. The serum calcium levels reached to $10.8 \mathrm{mg} / \mathrm{dl}$ when estimated after 16 days of post treatment.

Parturient paresis is caused by a decrease in calcium intake under conditions of increased calcium requirements, usually during late gestation (because most of the foetal bones calcification occurs in last month of gestation (GarrettR. Detzel1988), where the animal's body fails to maintain the calcium homeostasis following a sudden upsurge demand for calcium during gestation or lactation period (Goff, 2008 and Roberts et al., 2012), thus resulting in a low serum calcium concentration. Goff J.P (2008) documented that the normal serum calcium concentration range from 2.2 to $2.7 \mathrm{mmol} / \mathrm{L}$, whereas in milk fever, the parameter will be less than $1.5 \mathrm{mmol} / \mathrm{L}$. It occurs mostly in goats, particularly when more than one foetus is present in the uterus. The present findings are in agreement with (Radostits et al., 2006 \& Goff and RL Horst1997). Both hypocalcemia and milk fever are biochemically and clinically may be ascribed to a deficiency in available calcium (Capen and Rosol 1989 \& Radostits et al., 2006). 
Such cases should be was managed primarily with calcium supplementation in order to restore the serum calcium concentration and further to avoid muscle and nerve injury (Smith, 2009). The dose rate for intravenous administration of calcium borogluconate or subcutaneous injection was $1.5 \mathrm{~g}$ of calcium (Thilsing-Hansen et al., 2002; Miltenburg et al., 2016).

However, intravenous administration is always the choice of treatment due to the high and fast absorption rate. The intravenous administration of calcium gluconate has done slowly by monitoring heart beat as rapid infusion may lead to arrythmias and heart failure (Guss SB1977). Other supportive drugs like nervine tonic might be helpful due to multiple ingredients viz., methylcobalamine, pyridoxine, nicotinamide to decrease neurological disturbances and to increase nerve strength.

Management of periparturient paresis cases with oral calcium supplementation is mandatory in order to prevent suppression of parathyroid gland and further to prevent hypocalcemia after parturition (J.P Goff, 2000). Injecting vitamin D 10 to 14 days before calving to prevent hypocalcaemia was also suggested (Goff, 2008; Gammon 2014).

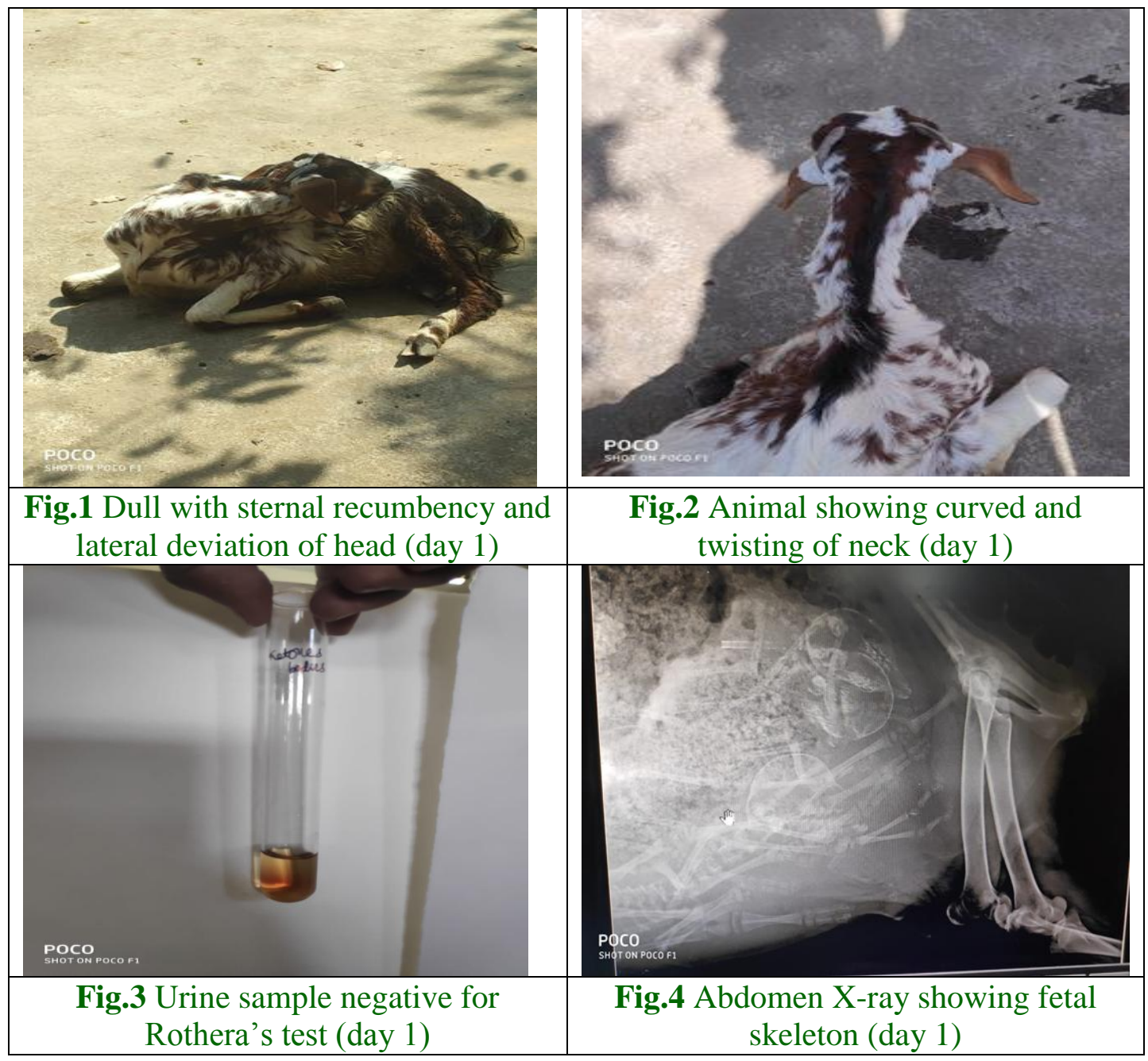




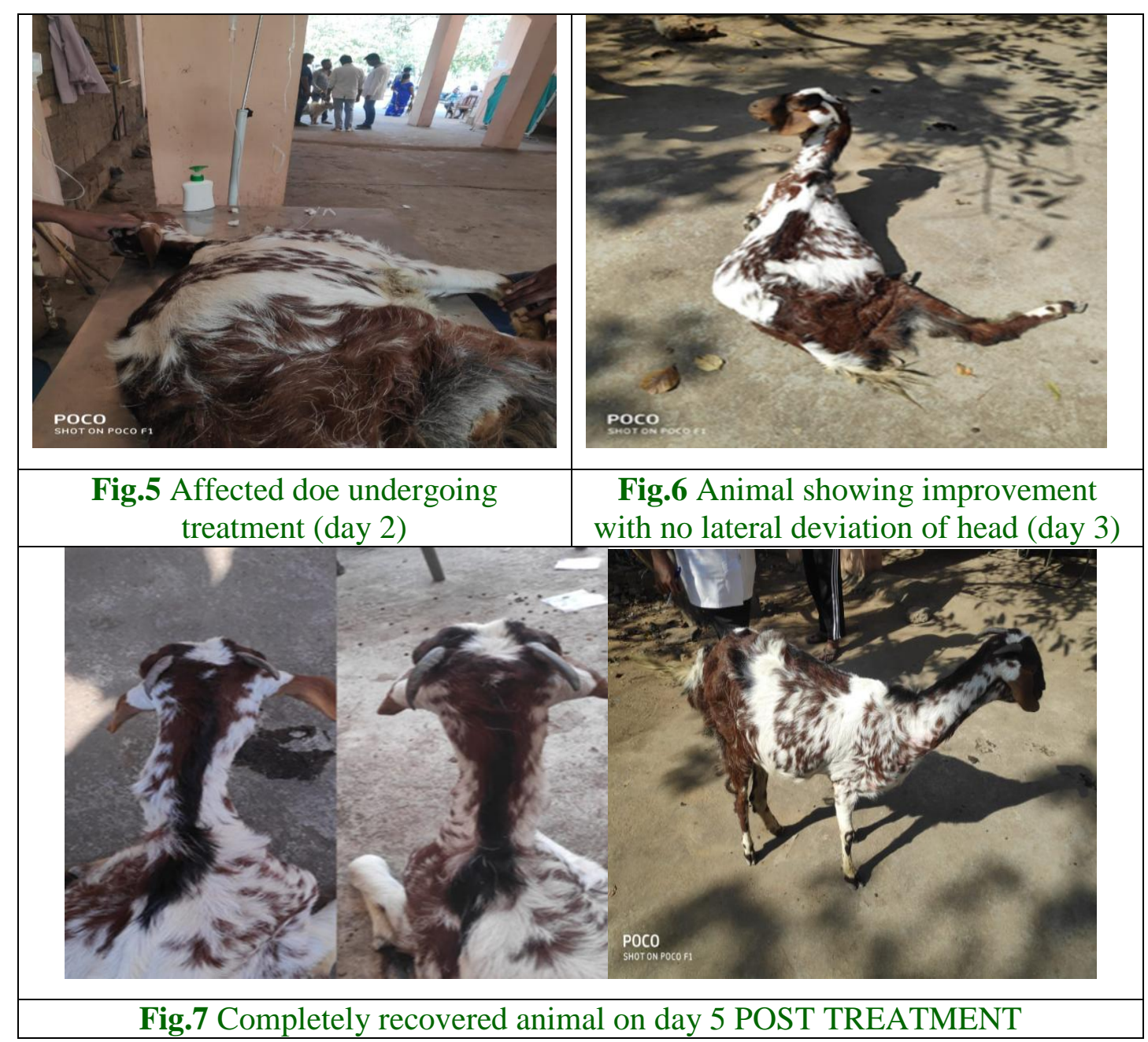

A non-descript doe of 3 years was presented with recumbency and was diagnosed for preparturient paresis based on serum calcium levels and presence of four feti on $\mathrm{x}$-ray. The case was successfully managed with intravenous calcium gluconate initially, followed by oral calcium supplementation.

\section{Acknowledgement}

The author wish to express sincere thanks to Dr.K. Satish Kumar, Professor \& University Head, Department of Veterinary Medicine, College of Veterinary Science, PVNR TVU and other teaching staff for providing the facilities and guiding us in successful completion of this case study.

\section{References}

Allen WM, Sansom BF: Parturient paresis (milk fever) and hypocalcemia (cows, ewes, and goats). In Howard JL (ed): Current Veterinary Therapy: Food Animal Practice: Volume 2. Philadelphia, WB Saunders, 1986, pp 311-317

Anderson, J. J. B. 1968. Parturient hypocalcemia. Conf. Parturient Paresis Dairy Anita, Academic Press, New York, NY.

Capen, C. C., and T. J. Rosol. 1989. Calciumregulating hormones and diseases of abnormal mineral metabolism. Pages 678-752 in Clinical Biochemistry of Domestic Animals. J. J. Kaneko, ed. 
$4^{\text {th }}$ Edition. Academic Press, San Diego, CA.

Curtis RA, Cote JF, McLennan MC, et al., Relationship of methods of treatment to relapse rate and serum levels of calcium and phosphorus in parturient hypocalcemia. Can Vet J 19:155-158, 1978.

Frank K Ramsey (1945) "Caprine Acetonemia Complicated with Parturient Paresis," Iowa State University Veterinarian: Vol. 8: Iss. 1, Article 13.

Gammon D (2014). Milk fever prevention: a clinical review of current prevention strategies. Livestock, 19(3): 142-146.

Garrett R. Detzel, Parturient Paresis and Hypocalcemia in Ruminant Livestock, Veterinary Clinics of North America: Food Animal practice- Vol. 4, No. 2, July 1988.

Goff J.P (2008). The monitoring, prevention, and treatment of milk fever and subclinical hypocalcemia in dairy cows. The Veterinary Journal, 176(1): 50-57.

Guss SB: Management and Diseases of Dairy Goats. Scottsdale, Arizona, Dairy Goat Journal Publishing Corporation, 1977, pp 86-88.

J.P Goff, RL Horst Physiological changes at parturition and their relationship to metabolic disorders J. Dairy Sci., 80 (1997), pp. 1260-1268

J.P Goff Pathophysiology of calcium and phosphorus disorders Vet. Clin. North
Am. Food Anim. Pract., 16 (2000), pp. 319-337.

Miltenburg CL, Duffield TF, Bienzle D, Scholtz EL, and LeBlanc SJ (2016). Randomozed clinical trial of a calcium supplement for improvement of health in dairy cows in early lactation. Journal of Dairy Science, 16:30313-7.

Pugh D.G. A Textbook of Sheep and goat Medicine. $1^{\text {st }}$ ed. (2002). Saunders an imprint of Elseviar, Philadelphia, Pennsylvania, U.S.A.pp.48-49.

Radostits, O. M., Gay C.C., HinchcliffK.W.,Constable P.D., Veterinary Medicine. A Textbook of the Diseases of Cattle, Sheep, Pigs, Goatsand Horses. 10th ed. (2006) W. B. Saunders Company Ltd. London, UK, pp.1626-1633.

Roberts T, Chapinal N, LeBlanc SJ, Kelton DF, Dubuc J, and Duffield TF (2012). Metabolic parameters in transition cows as indicators for early lactation culling risk. Journal of Dairy Science, 95(6): 3057-3063.

Smith BP (2009). Acute Hypocalcaemia (Milk Fever) in Dairy Cows. Large Animal Internal Medicine, 4th Edition. Missouri: Elsevier Saunders.

Thilsing-Hensen $\mathrm{T}$, Jorgensen $\mathrm{RJ}$, and Ostergaard S (2002). Milk fever control principles: a review. Acta VeterinariaScandinavica, 43: 1-19.

\section{How to cite this article:}

Babji. B. R., J. Jyothi and Abhinav Kumar Reddy. G. 2020. Diagnosis and Management of PrePartum Paresis in a Goat. Int.J.Curr.Microbiol.App.Sci. 9(05): 1029-1033. doi: https://doi.org/10.20546/ijcmas.2020.905.112 